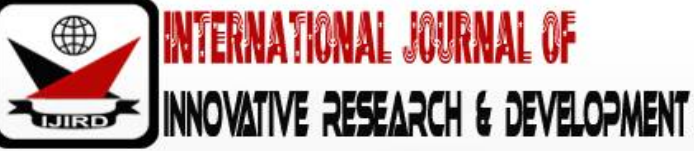

ISSN 2278 - 0211 (Online)

\section{Information Disclosure and Transparency, Islamic Work Ethics and Performance of Islamic Financial Institutions in Nigeria}

\author{
Sa'adatu Balarabe Adam \\ Ph.D Student, Islamic Business School, Universiti Utara Malaysia, Malaysia \\ Dr. Al-Hasan Al-Aidaros \\ Lecturer, Islamic Business School, Universiti Utara Malaysia, Malaysia \\ Dr. Suhaimi Bin Ishak \\ Lecturer, School of accounting, Universiti Utara Malaysia, Malaysia
}

\begin{abstract}
:
Nevertheless of the importance and applicability of Islamic corporate governance practices in contemporary financial institutions, the literature indicates very few studies have attempted to investigate the relationship among information disclosure and transparency, work ethics and performance of financial institutions from the Islamic perspectives, mainly the moderating effect of Islamic work ethics on the relationship between information disclosure and transparency and the performance of Islamic financial institutions (IFIs). The literature reveals that there is not only limited information on these practices of IFIs but also little research in this important area. By using structural questionnaires, the data for the study were collected from 254 IFIs in Nigeria. The finding of the study indicates Islamic Work Ethics moderates the relationship between information disclosure and transparency and performance of IFIs. The study contributes theoretically through the empirical testing of the moderating effect of Islamic work ethics on the relationship between information disclosure and transparency and performance of IFIs. At practical level, the study suggests that, in order to enhance performance through information disclosure and transparency, IFIs need to embrace Islamic work ethics. Therefore, this study suggests IFIs may need to operate according to Islamic values and principles for improved performance.
\end{abstract}

Kevwords: Information disclosure, transparencv, Islamic work ethics, performance

\section{Introduction}

In financial institutions, corporate governance practices are considered not only important but also means for improving organizational performance. The ability to practice good governance is crucial to protect the interest of stakeholders. Over decades, studies on the area of corporate governance continue to attract interest of researchers due to its complex nature in addressing corporate issues that have existed since the time of Adam Smith (Smith, 1776). For instance, the outcome of the meeting of G7 (G7 are 7 large advance economies in the globe comprises of Unites States of America, United Kingdom, Italy, Japan, Germany, Canada and France) leaders on the Asian financial and Russian debt crises of 1998, the Organization of Economic Cooperation Development (OECD) and researchers began to give priority to corporate governance (Tosuni, 2013). According to Organization for Economic Co-operation and Development (OECD) corporate governance is defined as "procedures and processes of directing and controlling in an organization, being the most popular concept of corporate governance in Western countries (Mizushima, 2014).

Therefore, financial institution serves as an apparatus where corporate governance practice becomes the driving force to its performance. Consequently, organizations need good corporate governance practices to perform successfully (Maati, 1999; Moradi, Velashani, \& Omidfar, 2017; Thrikawala, Locke, \& Reddy, 2013). Performance of financial institutions constitute economic and business activities that are responsible for achieving competitive advantage and contribute to economic growth. On the other hand, the performance of Islamic financial institutions (IFIs) is viewed on work accomplished and ethical conduct according to Islamic principles providing the best path way to achieve objectives (Mohamad, 2013).

Despite the importance of these corporate governance practices to IFIs, these practices have not attracted much research and interest. Particularly, the relationship among information disclosure and transparency, Islamic work ethics and performance of IFIs. Even the few studies that examined the relationship were presents incontinence findings. Therefore the objective of this study is to examine the moderating effect of Islamic work ethics on the relationship between information disclosure and transparency and the performance of Islamic financial institutions (IFIs). . 
Based on this information and research gaps, the paper is presented in five sections. The following Section Two is literature review. Next, Section Three is research methodology, section four present the results of the analyses, Finally, Section five presents conclusion of the paper.

\section{Literature Review}

Past studies which include Abdulazeez, Ndibe and Mercy (2016); Ajola, Amuda, and Arulogun (2012); as well as Odudu, James and James (2016) showed the need to examine transparency of board of directors and supervisory board in relation to performance of financial institutions in Nigeria. This is due to the financial failures that had adversely affected the confidence of investors on them (Odudu et al. 2016). Findings of some studies revealed insufficient number of members as the board of directors of financial institutions in Nigeria results in increased information disclosure problem leading to underperformance (Abdulazeez et al. 2016). They suggest that effective corporate governance is related to organizational performance and so number of members at the board should be within the code of governance limit. This is supported by the study Ajola et al. (2012), as well as Anderson, Mansi and Reeb, (2004), that transparency of the board has significant relationship with financial performance and that they influence managers to become more effective in achieving the best performance.

According to Bello and Abubakar (2014), presence of poor supervisory framework from the central bank of Nigeria is a great challenge faced by Islamic financial institutions in Nigeria. This results in ineffective supervision and lack of transparency of these institutions and causing contradictory issues between the two advisory bodies instead of complementing each other in the discharge of their duties.

Previous empirical studies such as Ranti (2011) as well as Sanda, Mukaila, and Garba (2000) have proved evidence that indicate gaps regarding less information disclosure and transparency in Nigeria. Specifically, Ranti (2011) has confirmed the increasing need for transparency in governing companies. This is supported by Sanda et al. (2005) that viewed disclosure and transparency a critical tool for corporate governance.

Similarly, lack of independence of audit committee in Nigerian private organizations affects their transparency and have not received much empirical examination (Ayodele et al. 2016). It is noteworthy that organizations now require great competence from audit practice as an important managerial control system for improved financial performance (Mohiuddin \& Karbhari, 2010).

Furthermore, the absence of investor participation on assets of the company affects performance of the organizations (Ranti, 2011). This is evident in the unethical and fraudulent practices among some organizations in Nigeria including Unilever Plc. indicating failure of existing corporate governance structure (Quadri, 2010). This resulted in investment account holders losing trust on the credibility of financial reports which were considered misleading and the absence of investor participation on assets of the company affects performance of the organizations (Ojeka, Iyoha \& Obigbemi, 2014; Ranti, 2011).

Moreover, studies paid attention to linkage between corporate governance and organizational performance (Ahmed, Ullah, Ahmed \& Rahman, 2016; Al-Tamimi, 2012; Bukhair \& Rahman, 2015; Hassan, 2011; Herdijiono \& Sari, 2017; Liem, 2016; Marri et al. 2016; Rammal, 2010). These studies are mainly of other countries such as Pakistan, Malaysia, Kuwait, Bahrain, Qatar, Saudi Arabia, United Kingdom, United Arab Emirates, Gulf Corporation countries, and United States of America. However, the findings from these studies are mixed and inconsistent. This is consistent with the few studies in Nigeria by Abdulazeez et al. (2016); Edrin, Ekwueme and Edesiri, (2015). In addition, theories that investigated past studies on corporate governance and performance did not sufficiently describe Islamic corporate governance (AbdelBaki \& Sciabolazza, 2014; Bukhari et al. 2013; Liem, 2016; Mollah \& Zaman, 2015, OECD, 2009). In view of this, Bukhair and Rahman (2015); Mollah and Zaman (2015); Safieddine, (2009), suggested that additional studies are needed to examine corporate governance and performance of IFIs.

There have been many studies on corporate governance and performance of IFIs showing several issues related to the methodology adopted, identified to include lack of theoretical framework to conceptualize and investigate factors that influence IFIs performance (Bello, 2016; Sapovadia, 2015), limited formulation and testing of research hypothesis (Garas \& Pierce, 2010; Hassan, Abdullah, Hassan, Ibrahim, Sawari, Aziz, \& Triyanta, 2013; Rammal, 2010), and small sample size used (Magalhães \& Al-Saad, 2013; Tom \& Biobele, 2015; Al-Arimi, Masrom \& Mahmood, 2016).

Performance of organizations is being related to Islamic work ethics (IWEs) (Abbasi, Ghulam, \& Muzammil, 2012). Studies show IWEs are linked to several individual and organizational outcomes. Marri, Sadozi, Zaman and Ramay (2016) further suggested that IWEs can be examined with organization performance. Yousef (2001) assessed the effect of moderation with Islamic work ethics on organizational commitment and job satisfaction, and his findings showed IWEs to affect organizational commitment and job satisfaction, concluded that organizations observe IWEs than manufacturing industries. Sadozai, Marri, Zaman, Yousufzai and Nas (2013) examined how IWEs moderate between organizational commitment and turn over intentions, developing the moderating model by adopting steps for measuring moderation from Baron \& Kenny, (1986). Recently, Khan, Abbas, Gul and Raja (2015) also used IWEs as moderator on the relationship between organizational justice and work outcomes.

\section{Research Methodology}

More importantly, the IFIs involved in this study are confined only to those that are registered with the Central bank of Nigeria (CBN). As such, list obtained from the CBN was used as the sampling frame. The framework assessed the performance of IFIs in relation to corporate governance practices and moderation with IWEs. 
The data for this study was collected through structural questionnaires. The structured questionnaires were addressed to the Managers and Senior Managers of the IFIs as the respondents. However, of the 400 IFIs, only 254 completed and returned the questionnaires.

The structured questionnaire used in this study comprised three sections. In the first section, five items were used to generate information regarding the background of the respondent. In the section two, the nine items used to measure Information disclosure and transparency. 11 items were used to measuring the Islamic work ethics and another nine items were used to measure the performance of IFIs. They were rated by using a seven numerical scale ranging from "Strongly disagreed" (1) to "Strongly Agreed" (7).

\section{The Results}

\subsection{Demographic Profile of Respondents}

This section describes the demographic profiles of the respondents in the sample. It presents the frequency distribution and percentage of participants by demographic characteristics. The respondents were asked to indicate a number of characteristics relating to their IFIs (performance of institution, information discloser and transparency and Islamic work ethics), as well as demographic variables (gender, age, years of experience, years of existence of institution and job title)

\begin{tabular}{|c|c|c|}
\hline Items & Frequency & Percentage \\
\hline \multicolumn{3}{|l|}{ Sex } \\
\hline Male & 187 & 73.6 \\
\hline Female & 67 & 26.4 \\
\hline \multicolumn{3}{|l|}{ Age } \\
\hline Under 30 Years Old & 83 & 32.7 \\
\hline 30-39 Years Old & 131 & 51.6 \\
\hline 40-50 Years Old & 37 & 14.6 \\
\hline Over 50 Years Old & 3 & 1.2 \\
\hline \multicolumn{3}{|c|}{ Experience in IFI } \\
\hline Less than 5 Years & 167 & 65.7 \\
\hline 6-10 years & 76 & 29.9 \\
\hline 11-15 Years & 9 & 3.5 \\
\hline 16-20 Years & 1 & 0.4 \\
\hline Over 20 Years & 1 & 0.4 \\
\hline \multicolumn{3}{|l|}{ Years of IFI } \\
\hline Less than 2 Years & 55 & 21.7 \\
\hline $2-5$ Years & 73 & 28.7 \\
\hline 5-10 Years & 116 & 45.7 \\
\hline More than 10 years & 10 & 3.9 \\
\hline \multicolumn{3}{|l|}{ Job Tittle } \\
\hline Managers & 61 & 24 \\
\hline Senior Management Cadre & 193 & 76 \\
\hline
\end{tabular}

Table 1: Demographic Profile of Respondents: Frequency Distribution (N=254)

As shown in Table 1 above, majority of respondents, 187, were male (73.6\%), with the remaining 67 (26.4\%) female. This wide range between male respondents and their female counterparts is not surprising considering that earlier studies on IFIs have testified that male respondents are always in the majority in both developing and developed nations (Al-Arimi et al., 2016; Daud et al., 2011; Mustapha et al., 2017; Yesil et al. 2012).

Participants were asked their position in their respective IFIs, to check their eligibility for completing the survey questionnaire and to distinguish who were managers and senior management cadre officers. Allowing people not in authority regarding corporate governance practice to fill the questionnaire could produce unreliable and biased results. Thus, the data indicates that the largest group of respondents were senior management cadre $(193,76 \%)$, followed by the managers $(61,24 \%)$.

The next category concerned the age of the firm. As shown in Table 1, the largest group of the IFIs participating in this study with longer period in existence have more than 10 years $(10,3.9 \%)$, at the time of the data collection, then 5-10 years of existence 116 respondents (45.7\%), IFIs existing 2-5 years, $73(28.7 \%)$ while IFIs with less than 2 years of existence is $55(21.7 \%)$.

Respondents with experience less than 5 years are 167 (65.7\%), 6-10 years of experience, 76 (29.9\%), 11-15 years, 9 (3.5\%), 16-20 years, 1 (.4\%) and over 20 years, 1(.4\%). Respondents under 30 years of age 83 forming (32.7\%), 
those between 30-39 years are 131 (51.6\%), those between 40-50 years are 37 (14.6\%) while those over 50 years old are $3(1.2 \%)$. This indicates that more than half the respondents that managed IFIs fall between the ages of 30-39 years in Nigeria.

\subsection{Descriptive Statistics of Latent Constructs}

In this section, the descriptive statistics of the latent variables are presented. The mean (the sum of all observed outcomes from the sample divided by the total number of events) and standard deviation (SD, the measure used to quantify the amount of variation or dispersion of a set of data values) were computed to determine the descriptive characteristics of the variables, as shown in Table 2

\begin{tabular}{|c|c|c|c|}
\hline Construct & Sample & Mean & Std. Deviation \\
\hline $\begin{array}{c}\text { Information Disclosure \& Transparency } \\
\text { (IDT) }\end{array}$ & 254 & 5.067 & 0.834 \\
\hline Islamic Work Ethics (IWEs) & 254 & 5.359 & 0.813 \\
\hline Performance & 254 & 5.238 & 0.718 \\
\hline
\end{tabular}

Table 2: Descriptive Statistics of Latent Constructs

As discussed in chapter 3, all the constructs were measured on a 7-point Likert scale, from $1=$ Strongly disagree 7 $=$ Strongly agree.

As referred to Table 4.8, the mean and SD for IDT with 5.067 and a SD at .834 indicating that the respondents tended to agree with the statements concerning this construct. Similar outcomes were found for the moderating variable, IWEs at 5.359 and .813. For the dependent variable, IFIs' performance, the mean was 5.238 and SD .718, which also indicates moderate agreement with the statements indicating the reality and practicability of the concepts in their respective IFIs. The means of the latent variables show that the average option chosen by respondents was moderate agreement. The data points were close to the mean, with little deviation (Bhatti, Hoe \& Sundram, 2012).

\subsection{Assessment of Measurement Model}

Assessment of measurement model (the outer model) was the first step in PLS-SEM analysis. It deals with components that determine how good the survey items measure the constructs they were designed to measure, hence ensuring that the model is reliable and valid. The assessment of outer model consists of determining individual items' reliability, internal consistency, content validity, convergent validity and discriminant validity (Hair, et al., 2011; Hair, et al., 2016).

\subsection{Individual Item Reliability}

In determining the individual item (indicators) reliability and other measurement model assessments, the researcher performed the PLS algorithm (Geladi \& Kowalski, 1986) as represented in Figure 4.3 above. The outer loadings of each construct's measure were examined ( Hair, et al., 2014), using Hair et al.'s (2014) rule of thumb for retaining only the items with loadings between .40 and .70, subject to an increase of average variance extracted (AVE) and composite reliability (CR). Out of 65 items, 13 were deleted (PER3, PER6, PER8, PER9,IDT5, IDT6,IWEs4, IWEs7, IWEs8)because they presented loadings below the threshold of 0.40 (Hair et al., 2014). Thus, in the whole model, only 52 items were retained; their loadings between .556 and .864 were considered acceptable for further analysis.

\subsection{Internal Consistency Reliability}

The extent to which the entire items of a particular scale are measuring the same concept is known as internal consistency reliability (Bijttebier et al., 2000; Sun et al., 2007). Traditionally, Cronbach's alpha coefficient is the measure for assessing internal consistency giving an estimate of reliability based on the inter-correlations among.

Nevertheless, the popularity of the alpha coefficient has been criticised for being sensitive to the number of items in a construct and underrating the true internal consistency reliability; therefore, Composite Reliability (CR) is recommended as an alternative measure, especially in SEM (Bacon, Sauer \& Young, 1995; Hair et al., 2014; Peterson \& Kim, 2013). Composite Reliability consider the various outer loadings of individual indicators and it provide a less biased estimate of reliability than Cronbach's alpha, which assumes all items are equally reliable without seeing the actual contribution of each individual's loadings ( Barclay, Higgins, \& Thompson,1995; Götz, Liehr-Gobbers \& Krafft, 2010; Hair et al., 2014). Therefore, it was suggested that CR is more appropriate for PLS-SEM (Hair et al., 2014), and the present study used it for assessing internal consistency reliability. Table 3 presents the loadings, CRand AVE. 


\begin{tabular}{|c|c|c|c|}
\hline & Standardized & Composite & Average \\
\hline \multirow[t]{3}{*}{$\begin{array}{l}\text { Latent Constructs and } \\
\text { Indicators } \\
\end{array}$} & Loadings & Reliability & Variance \\
\hline & & $(\mathrm{CR})$ & Extracted \\
\hline & & & $(\mathrm{AVE})$ \\
\hline Performance & & \multirow[t]{6}{*}{0.836} & \multirow[t]{6}{*}{0.507} \\
\hline PER1 & 0.693 & & \\
\hline PER2 & 0.786 & & \\
\hline PER4 & 0.762 & & \\
\hline PER5 & 0.706 & & \\
\hline PER7 & 0.597 & & \\
\hline $\begin{array}{l}\text { Information Disclosure \& } \\
\text { Transparency }\end{array}$ & & \multirow[t]{8}{*}{0.875} & \multirow[t]{8}{*}{0.502} \\
\hline IDT1 & 0.611 & & \\
\hline IDT2 & 0.79 & & \\
\hline IDT3 & 0.669 & & \\
\hline IDT4 & 0.701 & & \\
\hline IDT7 & 0.749 & & \\
\hline IDT8 & 0.747 & & \\
\hline IDT9 & 0.675 & & \\
\hline Islamic Work Ethics & & \multirow[t]{9}{*}{0.898} & \multirow[t]{9}{*}{0.531} \\
\hline IWEs1 & 0.803 & & \\
\hline IWEs2 & 0.86 & & \\
\hline IWEs3 & 0.854 & & \\
\hline IWEs5 & 0.671 & & \\
\hline IWEs6 & 0.598 & & \\
\hline IWEs9 & 0.633 & & \\
\hline IWEs10 & 0.776 & & \\
\hline IWEs11 & 0.566 & & \\
\hline
\end{tabular}

Table 3: Loadings, Composite Reliability and Average Variance Extracted

Referring above, the researcher used the rule of thumb provided by Hair et al. (2011) for interpretation of the internal consistency reliability using a CR coefficient, which should be at least .70. Therefore, as can be seen from Table 4.9, apart from the 13 items that were removed for the reasons explained above, all other indicators have loadings of .80 and above.

\subsection{Convergent Validity}

Convergent validity discusses a type of reflective construct's validity that evaluates how a certain item essentially measures what it was proposed to measure, and it correlates positively with other items belonging to the same construct (Hair et al., 2006). The construct is expected to have convergent validity when its items share a high percentage of variance (Hair, et al., 2014).

Fornell and Larcker (1981) suggested that, convergent validity was measured by assessing the AVE of each latent construct. To achieve adequate convergent validity, AVE of each latent construct should be .50 or more (Chin, 1998). The AVE values (see Table 4.9) revealed high loadings (>.50) on their individual constructs, suggesting adequate convergent validity.

In line with the PLS-SEM algorithm results (Geladi \& Kowalski, 1986; Lohmoeller, 1989) presented in Table 4.9, Performance has the AVE value of .507, IDT .502 and IWEs .531. These values indicate that, all the reflective constructs mentioned above, have convergent validity, and explained more than $50 \%$ of the variance of their individual items.

\subsection{Discriminant Validity}

Discriminant validity is another form of reflective construct validity that presents the extent to which a particular construct is distinct from other constructs of the same model, based on empirical findings (Hair et al., 2014). A latent reflective construct is said to present discriminant validity when it reveals a unique phenomenon not characterized by other latent reflective constructs, (Hair et al., 2014).

There are two approaches to assessing discriminant validity (Hair et al., 2014). The first method is referred to as the Fornell-Lacker criterion: that is, when the square root of AVE for a reflective construct is higher than its correlation with any other reflective construct in the same model, it indicates discriminant validity (Fornell \& Larcker, 1981). The aim of this method is that if the square root of the AVE of the latent reflective construct is higher than its correlation with other reflective latent constructs, it indicates that a certain construct shares more variance with its related indicators than with any other latent construct in the model. Therefore, this reflective construct is distinct from other constructs (Hair et al., 2014). Applying this method shows all the reflective latent constructs of this study achieved discriminant validity 


\begin{tabular}{|c|c|c|c|}
\hline Constructs & IDT & IWEs & \\
\hline IDT & 0.7089 & & \\
\hline IWEs & 0.632 & 0.7288 & 0.7122 \\
\hline PER & 0.5038 & 0.4139 & \\
\hline
\end{tabular}

Table 4: Measurement Model: Discriminant Validity (Fornell-Larcker Criterion)

The second method for assessing the discriminant validity of reflective latent variables is by examining the crossloadings of their individual indicators (Hair et al., 2014). Precisely, in order to have discriminant validity for a reflective latent variable using the cross-loadings method, all its indicator loadings should be greater than their corresponding loadings, that is, cross-loadings of other constructs (Chin, 1998). Hair et al. (2011) believed that cross loading is mostly considered a relatively liberal measure in establishing discriminant validity.

\subsection{Testing the Moderating Effects}

The result of the hypothesis testing shows that IWEshas a significant moderating effect on the relationship between IDT and IFI's performance. The interaction term of IDT*IWEs and IFIs' performance is significant $(\beta=0.14$; $\left.\mathrm{t}=2.13^{* *}\right)$, as shown in Table below; thus, $\mathrm{H1}$ is supported. Table below presents the results of the moderation hypothesis.

\begin{tabular}{|c|c|c|c|c|c|}
\hline Hypothesis & Relationships & Beta ( $\boldsymbol{\beta})$ & SE & T Statistics & Decision \\
\hline H1: & IDT * IWEs - P PER & 0.14 & 0.07 & $2.13^{* *}$ & Supported \\
\hline
\end{tabular}

Table 5: Results of the Moderation Hypothesis

Note: **Significant At 0.01 (One Tail), *Significant at 0.05. (One Tail)

PER=Ifis Performance, IDT=Information Disclosure \& Transparency, Iwes=Islamic Work Ethics

\section{Conclusions}

This study attempted to examine the moderating effect of IWEs on the relationship between information disclosure and transparency and performance of IFIs. The statistical result of this study showed IDT to positively relate to IFIs performance; thus, Hypothesis is supported $\left(\beta=0.14 ; \mathrm{t}=2.13^{* *}\right)$ the results of the analyses as presented in table 3 indicates showed that Islamic work ethics significantly moderates the relationship between IDT and IFIs performance. The result of this study provides some empirical evidence that suggest that Islamic work ethics and information disclosure have influence on the performance of IFIs (Bukhari et al., 2013; Al-Tamimi, 2012; Hasan, 2011; Ahmed, 2014). The study contributes theoretically through the empirical testing of the moderating effect of IWEs on the relationship between information disclosure and transparency and performance of IFIs. At practical level, the study suggests that, in order to enhance performance through information disclosure and transparency, IFIs need to embrace Islamic work ethics. Therefore, this study suggests IFIs may need to operate according to Islamic values and principles for improved performance.

\section{References}

i. Abbasi, A. S., Ghulam, M. M. and Muzammil, H. (2012). Islamic work ethics: How they affect organizational learning innovation and performance. Actual problems of Economics, (138) 12, 280-471.

ii. Adams, J. (1996). Principals and agents, colonialists and company men: The decay of colonial control in the Dutch East Indies, American sociological review, 61(1), 12-28.

iii. Abdulazeez, D.A., Ndibe, L., and Mercy, A.M. (2016). Corporate governance and financial Performance of Listed Deposit Money Banks in Nigeria. Journal of Accounting and Marketing.

iv. Abdel Baki, M. and Leone Sciabolazza, V. (2014). A consensus-based corporate governance paradigm for Islamic banks. Qualitative research in financial markets. 6(1), 93-108.

v. Adebayo, R. I. (2010). Adebayo, Rafiu Ibrahim. \&quot;The challenges and opportunities of Islamic Studies in the World of modern cyber-technologies: The Nigeria example. Regional Conference on Knowledge Integration in ICT. Ajola, O., Amuda, T. \& Arulogun, L. (2012). Evaluating the effects of corporate governance on the performance of Nigerian banking sector. Review of contemporary business research, (1), 32-42.

vi. Anderson. R., Mansi, S. \& Reeb, D. (2004). Board characteristics, accounting report, integrity and cost of debt. Journal of accounting and economics, (37), 315-342

vii. Ahmed Haji, A. (2014). The relationship between corporate governance attributes and firm performance before and after the revised code: Some Malaysian evidence. International journal of Commerce and Management, 24(2), 134-151.

viii. Ahmed, H. Z., Khan, NUA. \& Ahmad, Z. (2016). The concept performance measurement system in Islam, AL-ADWA, 45(31) 101-116.

ix. Ahmed, S. U., Ullah, G. W. N., Ahmed, S. P. \& Rahman, A. (2016). An empirical study on Corporate governance and Islamic bank performance: A study of Bangladesh. International journal of Finance and Banking Studies,5 (4),2147-4486.

x. Al-Aidaros, A. H. M. H. (2012). The Accountant's ethical code of conduct and moral reasoning from an Islamic environment: Case in Yemen (Doctoral dissertation, University Utara Malaysia).

xi. Al-Aidaros, A., Shamsudin, F. \& Idris, K. M. (2013). Ethics and ethical theories from an Islamic perspective. International journal of Islamic thought, vol. 4.

xii. A'la-Mawdudi. A. A. (1967). Islamic way of life, Islamic Research Academy, Karachi, Pakistan. 
xiii. Al-Arimi, A. A. A., Masrom, M. \& Mahmood, N. H. N. (2016) The moderating effect of Islamic work ethics on the relationship between knowledge management capabilities and organizational performance at the private Higher Education Institutions in Oman, Journal of Theoretical and Applied Information Technology, 94 (2), 396-407.

xiv. Alawiye-Adams A. A. and Babatunde, A. (2013). Corporate governance: Its impact on stakeholders and efficient bank management in Nigeria. SSRN:https:/ / ssrn.com/ abstract=2316732.

xv. Al-Banna, (1940). Messages' group of Imam Hasan al-Banna (1 1st ed.). Alexandria: Darul Al-D’aoah Publication.

xvi. Albassam, W. M. and Ntim, C. G. (2017). The effect of Islamic values on voluntary corporate disclosure: A case of Saudi-listed firms, Journal of Islamic accounting and business research, 8(2), 182-202.

xvii. Aldulaimi, S. H. (2016). Fundamental Islamic perspective of work ethics, Journal of Islamic Accounting and Business Research, 7 (1), 59-76.

xviii. Al-Tamimi, H. A. H. (2012). The effects of corporate governance on performance and financial distress, Journal of Financial Regulation and Compliance,20(2), 169-186.

xix. Baron, R. M., \& Kenny, D. A. (1986). The moderator-mediator variable distinction in social psychological research: Conceptual, strategic, and statistical considerations. Journal of Personality and Social Psychology, 51(6), 11731182.

xx. Bacon, D. R, Sauer, P. L., \& Young, M. (1995). Composite reliability in structural equations modeling. Educational and Psychological Measurement, 55(3), 394-406.

xxi. Bello, A. (2016). Islamic banking products and challenges in Nigeria, Sahara Reporters.

xxii. Bijttebier, P., Delva, D., Vanoost, S., Bobbaers, H., Lauwers, P., \& Vertommen, H. (2000). Reliability and validity of the Critical Care Family Needs Inventory in a Dutch-speaking Belgian sample. Heart \& Lung: The Journal of Acute and Critical Care, 29(4), 278-286.

xxiii. Bukair, A. A. and A. Abdul Rahman (2015). Bank performance and board of directors attributes by Islamic banks. International journal of Islamic and Middle Eastern Finance and Management, 8(3): 291-309.

xxiv. Bukhari, K. S., Awan, H. M., Ahmed, F. (2013). An evaluation of corporate governance of Islamic banks versus Islamic banks windows of conventional banks: A case of Pakistan, Management research review, 36(4), 400-416.

xxv. Bukair, A. A. and A. Abdul Rahman (2015). Bank performance and board of directors attributes by Islamic banks. International journal of Islamic and Middle Eastern Finance and Management 8(3): 291-309.

xxvi. Bhatti, M. A., Hoe, C. H., \& Sundram, V. P. K. (2012). A Guide for Beginners Data Analysis Using SPSS a nd AMOS. Pearson Malaysia.

xxvii. Chin, W. W. (1998). The partial least squares approach to structural equation modeling. Modern Methods for Business Research, 295(2), 295-336.

xxviii. Chin, W. W., Marcolin, B. L., \& Newsted, P. R. (2003). A partial least squares latent variable modeling approach for measuring interaction effects: Results from a Monte Carlo

xxix. Geladi, P., \& Kowalski, B. R. (1986). Partial least-squares regression: a tutorial. Analytica Chimica Acta, 185, 1-17.

xxx. Hair, J. F., Black, W. C., Babin, B. J., \& Anderson, R. E. (2010). Multivariate data analysis: A Global Perspective.Upper Saddle River, NJ: Pearson, (2009. Print).

xxxi. Hair, J. F., Ringle, C. M., \& Sarstedt, M. (2011). PLS-SEM: Indeed a silver bullet. Journal of Marketing Theory and Practice, 19(2), 139-152.

xxxii. Hair, J. F., Sarstedt, M., Ringle, C. M., \& Mena, J. A. (2012). An assessment of the use of partial least squares structural equation modeling in marketing research. Journal of the Academy of Marketing Science, 40(3), 414433.

xxxiii. Hasan, Z. (2011). A survey on shariah governance practices in Malaysia, GCC countries and the UK: critical appraisal, International journal of Islamic and Middle Eastern Finance and Management, 4(1), 30-51.

xxxiv. Khan, A., Tanveer, S., Shah, A. Q., \& Jamil, R. A. (2015). Comparative analysis of regulatory and supervisory system of Islamic banks: Evidence from Pakistan, Malaysia, Bahrain and United Kingdom. Mediterranean Journal of Social Sciences, 6(6 S2), 629.

xxxv. Khan, B., Farooq, A. \& Hussain (2010). Human resource management: An Islamic perspective, Asia-Pacific Journal of Business Administration, 2(1), 17-34.

xxxvi. Khan, K., Abbas, M., Gul, A. \& Raja, U. (2015). Organizational justice and job outcomes: Moderating role of Islamic work ethics, Journal of Business Ethics, 126,235-246.

xxxvii. Lohmoeller, J.-B. (1989). Latent variable path analysis with partial least squares. New York: Springer-Verlag. Handbook of partial least squares, 427-447. Springer.

xxxviii. Maati, J. (1999). The Governance Entraprises. Oxford University Press, New York, NY and Oxford.

xxxix. Marri, M. Y. K., Sadozi, A. M., Zaman, H. M. F. \& Ramay, M. I. (2016). The impact of Islamic work ethics on job satisfaction and organizational commitment: A study. of agricultural sector of Pakistan, International Journal of Business and Behavioural Sciences, 2(12), 32-44.

xl. Mizushima, T. (2014). Corporate governance and shariah governance at Islamic financial institutions: Accessing from current practice in Malaysia. Reitaku Journal of Interdisciplinary Studies, 22(1), 59-84.

xli. Moradi, M., Velashani, M. A. B., \& Omidfar, M. (2017). Corporate governance, product market competition and firm performance: evidence from Iran. Humanomics, 33(1), 33-55.

xlii. Mohammed, F. (2012). Impact of corporate governance on banks performance in Nigeria. Journal of emerging trends in Economics and Management Science (JETEMS) 3(3), 257-260.

xliii. Mohiuddin, G. (2012). Controlling an Islamic perspective, Research Journal of Finance and Accounting, 3(9), 108113. 
xliv. Odudu, A. S., James, O. A. and James, O. U. (2016). Board characteristics and financial performance of deposit money banks in Nigeria, International journal of business and social science, (7), 9.

xlv. Ojeka, S. A.; Iyola, F. O. \& Obigbemi, I. F. (2014). Effectiveness of Audit committee and firm financial performance in Nigeria: An empirical analysis, Journal of accounting and auditing: Research and practice, vol.39

xlvi. Peterson, R. A., \& Kim, Y. (2013). On the relationship between coefficient alpha and composite reliability. Journal of Applied Psychology, 98(1), 194-198.

xlvii. Qadri, A. H. (2010). Conceptual framework for corporate governance in Nigeria: Challenges and Panaceas, PM World Today, X11(1X).

xlviii. Thrikawala, S. S., Locke, S., \& Reddy, K. (2013). Corporate governance - performance relationship in microfinance institutions (MFIs). Asian Journal of Finance \& Accounting, 5(1), 160-182.

xlix. Ranti, U. O. (2011). Corporate governance and financial performance of banks: A study of listed banks in Nigeria. A $\mathrm{PhD}$ thesis desertion, Covenant University, Ogun state.

1. Sadozai, A. M., Marri, M. Y. K., Zaman, H. M. F., Yousufzai, M. I., \& Nas, Z. (2013). Moderating role of Islamic work ethics between the relationship of organizational commitment and turnover intentions: A study of public sector of Pakistan. Mediterranean Journal of social sciences, 4(2), 767.

li. Sanda, A. U., Mukaila, A. S. \& Garba, T. (2005). Corporate governance mechanism and firm financial performance in Nigeria. Final report presented to the biannual research workshop of the AERC, Nairobi, Kenya, 24-29.

lii. Tosuni, G. (2013). The impact of corporate governance on the performance of financial institutions. A PhD thesis submitted to Staffordshire University. 